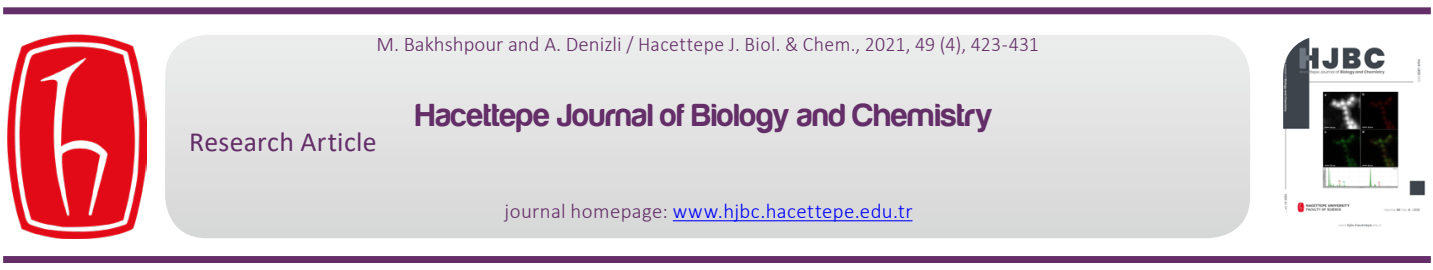

\title{
Preparation of Bacterial Cellulose/Vinyl Imidazole-Based Membranes for Selective Purification of Hemoglobin
}

\section{Hemoglobinin Seçici Saflaştırılması için Bakteriyel Selüloz/Vinil Imidazol Bazlı Membranların Hazırlanması}

\author{
Monireh Bakhshpour ${ }^{\circledR}$, Adil Denizli ${ }^{\odot}$ \\ Biochemistry Division, Department of Chemistry, Hacettepe University, Ankara, Turkey.
}

\section{ABSTRACT}

T

he development of new biomaterials is needed to use in many areas such as protein purification, removal and drug release system. In this study, we fabricated hemoglobin $(\mathrm{Hb})$ surface imprinting onto the bacterial cellulose nanofibers. The metal ions coordination was obtained with vinyl imidazole and $\mathrm{Ni2}+$ ions. The selective purification of $\mathrm{Hb}$ was obtained using $\mathrm{Hb}$-imprinted bacterial cellulose. The Scanning Electron Microscopy, Surface area, Transformed Infrared Spectroscopy, swelling tests and contact angle measurements were used for the characterization of $\mathrm{Hb}$-imprinted and non-imprinted bacterial cellulose membranes. In addition, the adsorption studies were experimented with using the $\mathrm{Hb}$ aqueous solution in the batch systems at $2 \mathrm{~h}$. In this study, the prepared bacterial cellulose was reported as unique biomaterials for selective and sensitive purification of $\mathrm{Hb}$ with high adsorption capacity. The reusability of bacterial celluloses was demonstrated during the experiment.

\section{Key Words}

Purification, ions coordination, bacterial cellulose, hemoglobin.

\section{öz}

\begin{abstract}
Protein saflaştırma, uzaklaştırma ve ilaç salınımı gibi birçok alanda kullanılmak üzere yeni biyomalzemelerin geliştirilmesine ihtiyaç vardır. Bu çalışmada, bakteriyel selüloz nanofiberların üzerine yüzey baskılama yöntemi ile hemoglobin ( $\mathrm{Hb}$ ) baskılanmıştır. Metal iyonlarının koordinasyonu vinil imidazol ve Ni2+ iyonları ile elde edildi. Hb'nin seçici saflaştırılması, Hb baskılı bakteriyel selüloz kullanılarak elde edildi. Hb baskılanmış ve baskılanmamış bakteriyel selüloz nanofiberlerin karakterizasyonu için Taramalı Elektron Mikroskobu, Yüzey alanı, Dönüştürülmüş Kızılötesi Spektroskopisi, şişme testleri ve temas açısı ölçümleri kullanıldı. Ek olarak, adsorpsiyon çalışmaları Hb sulu çözeltisi kullanılarak 2 saatte kesikli sistemlerde deneylenmiştir. Bu çalışmada, hazırlanan bakteriyel selüloz, yüksek adsorpsiyon kapasitesine sahip Hb'nin seçici ve hassas saflaştırılması için benzersiz biyomateryaller olarak rapor edildi. Bakteriyel selülozların yeniden kullanılabilirliği deney sırasında gösterildi.
\end{abstract}

\section{Anahtar Kelimeler}

Saflaştırma, iyon koordinasyonu, bakteriyel selüloz, hemoglobin.

Article History: Received: Apr 19, 2021; Revised: May 10, 2021; Accepted: May 11, 2021; Available Online: Jun $10,2021$.

DOI: https://doi.org/10.15671/hjbc.921540

Correspondence to: A. Denizli, Department of Chemistry, Hacettepe University, Ankara, Turkey.

E-Mail: denizli@hacettepe.edu.tr 


\section{INTRODUCTION}

The he molecularly imprinted technologies are based on the polymerization of the appropriate cross-linker around a target molecule using specific recognition functional monomer [1]. Molecularly imprinted technology is used in many areas such as purification, separation, biomarker detection, and drug delivery systems [2]. Three main steps can be explaining for molecularly imprinted process: (a) a polymer matrix containing target molecule that is attached to the specific functional monomers [3]; (b) to obtain the specific and selective binding cavities on the surface of polymeric matrices, the target molecule is removed from the polymer, and (c) the selective rebinding steps for the sample containing the target molecule $[4,5]$. There are some challenges in the molecularly imprinted technology such as heterogeneous binding caused by multiple functional regions, slow mass transfer. Surface imprinting can be overcome these challenges. The selective and specific binding cavities are prepared at the polymeric matrix surface in the surface imprinting technique. Therefore, these sites are easier reachable for the binding of the target molecules. The surface imprinting technique generally is preferred for the imprinting of macromolecules.

Bio-based polymers with a high degree of complexity and added value are securing a place in non-traditional sectors by adapting processing approaches from the semiconductor and synthetic polymers technologies. Bacterial cellulose $(\mathrm{BC})$ is a biocompatible polysaccharide produced by bacteria currently used in many areas. Bacterial cellulose nanofibers are showing up charming biomaterials with high volume ratio and surface [6-10]. $\mathrm{BC}$ grows at the interface between the bacterial broth and the air, generating a robust hydrogel formed by randomly distributed intertwined nano cellulosic fibers.

There are many advantages such as biocompatibility, tensile strength, and combustible properties to use in the purification of proteins [11-13]. Bacterial cellulose is obtained as a broad bio-polymer in the nature. BC properties, namely, porosity, crystallinity, water holding capacity, biocompatibility, and outstanding mechanical properties have promoted it as an exceptional material employed in such diverse fields.

The bacterial cellulose can increase the mechanical characteristics of the nano-composite/bio-composite materials $[14,15]$. The three-dimensional bacterial cellulose nanofibers are produced by Agrobacterium microorganisms. $B C$ nanofibers offer unique properties to use as a biopolymer. Furthermore, the application landscape of $\mathrm{BC}$ is constantly expanding fostered by the versatility and facile fabrication of hydrogels with controlled porosity, composites or self-standing 3D structures. The numerous hydroxyl $(-\mathrm{OH})$ groups on the $B C$ nanofibers surface cause an excellent platform for the various area. There exists a significant demand for the production of hemoglobin $(\mathrm{Hb})$ based oxygen carriers $\left(\mathrm{HBO}_{2} \mathrm{Cs}\right)$ which present promising alternatives to the blood obtained via donation. The $\mathrm{HBO}_{2} \mathrm{Cs}$ can be utilized in blood shortages and in various medical application areas such as surgery, ischemia and internal hemorrhaging, etc. The major step for the synthesis of $\mathrm{HBO}_{2} \mathrm{Cs}$ is the purification of $\mathrm{Hb}$, which can be obtained by lysing red blood cells [16-18]. Recently, fabrication effective, selective, cheap, and easy methods for $\mathrm{Hb}$ purification is of great interesting in the biomedical area [19].

The specific interactions between the imidazole groups on the functional monomer and the metal ions can occur a specific recognition for target molecules which be imprinting. The metal ions coordination plays $[20,21]$ a significant role in molecular imprinting technology owing to the stability and specificity of orienting proteins [22]. Also, metal ions coordination is a fast binding process for the protein molecule in molecular imprinting technology $[15,23,24]$.

Here, Hb imprinted (MIP) bacterial cellulose was prepared using vinyl imidazole $(\mathrm{VI})$ as functional monomer and $\mathrm{Ni}$ as metal ions coordination to prepare interaction between $\mathrm{Hb}$. The characterization studies were obtained with SEM, FTIR, surface area measurements, contact angle and swelling tests. The selectivity studies of MIP bacterial cellulose were studied using Bovine Serum Albumin (BSA), Myoglobin (Myo), Cytochrome c (Cyt c) and Lysozyme (Lyz).

\section{MATERIALS and METHODS}

\section{Materials}

Lysozyme, Hemoglobin, Cytochrome c, Bovine Serum Albumin and Myoglobin were supplied from Aldrich, Munich, Germany. N,N',methylene-bisacrylamide (as a cross-linker (MBAAm)), 2-hydroxyethyl methacrylate (as a monomer (HEMA)) and N-vinylimidazole (VI), 3-methacryloxypropyltrimethoxysilane (3-MPS) were obtained from Sigma (St. Louis, USA). Azobisisobutyro- 
nitrile (as an initiator (AIBN)) was obtained from Fluka, Switzerland. Acetobacter xylinum (ATCC 10245) was purchased from Agricultural Research Service Culture Collection (ARS, USA).

\section{Preparation of pre-complex}

Firstly, vinyl imidazole (VI) as functional monomer and $\mathrm{Ni}^{2+}$ metal ions as a metal coordinated ions were complexed in the $1: 1$ molar ratio at $25^{\circ} \mathrm{C}$ temperature for 45 min (25 rpm). Then the $\mathrm{Hb}$ as a target molecule were added into the $\mathrm{VI-Ni}{ }^{+2}$ pre-complex and mixed for 30 min in the rotator. Therefore, the specific sites can be obtained with metal ions for target molecule. The nitrogen donor atoms in the imidazole of the VI have great affinity towards $\mathrm{Ni}^{2+}$ ions. The UV spectra was used for characterization of the binding between the $\mathrm{Hb}$, functional monomer, and metal ions [25].

\section{Preparation of MIP based bacterial cellulose}

Acetobacter xylinum was used for obtaining bacterial cellulose as reported in previous studies $[11,12,14,15,24]$. The BC nanofibers were washed with deionized water and then \%3 (V/V) 3-methacryloxypropyltrimetoxysilane, (3-MPS/toluene) was used to silane the BC. The BC was washed with methanol (\%99) and then deionized water for five times, respectively. The molecularly surface imprinted $\mathrm{BC}$ were prepared using $\mathrm{VI}-\mathrm{Ni}^{2+}-\mathrm{Hb}$ precomplex and PHEMA/MBAAm, monomer/cross-linker solution. The solutions and $\mathrm{BC}$ nanofibers were allowed to polymerize in the presence of (\%4 W/V) AIBN under $100 \mathrm{~W}$, UV light source for $40 \mathrm{~min}$. The removal process was carried out using $1.0 \mathrm{M} \mathrm{NaCl}$ solution. The removing of $\mathrm{Hb}$ was reported with spectrophotometrically. The NIP nanofibers were prepared without adding hemoglobin to pre-complexation solution with the same methods that used for preparation of MIP bacterial cellulose. Figure 1 shows the schematic preparation of $\mathrm{Hb}$ imprinted BC nanofibers.

\section{Characterization of bacterial cellulose}

UV-vis spectrophotometry was used for proving the formation of the pre-complex in the range of $200 \mathrm{~nm}-700$ nm (Shimadzu UV-1601, Shimadzu Crop., Kyoto, Japan). The structure of the $\mathrm{Hb}$-imprinted and non-imprinted bacterial cellulose were demonstrated with Scanning Electron Microscopy, SEM (Jeol JSM-5600; Tokyo, Japan). Transformed Infrared Spectroscopy (FTIR) spectra were reported (Nicolet iS10, Thermo Fisher Scientific, USA) to show the characteristic bonds of the functional monomers into the $\mathrm{Hb}$-imprinted and non-imprinted bacterial cellulose membrane structures. The leakage of $\mathrm{Ni}^{+2}$ ions from the bacterial cellulose structure were used Atomic Absorption Spectrophotometry (Analyst 800/Perkin Elmer, USA).

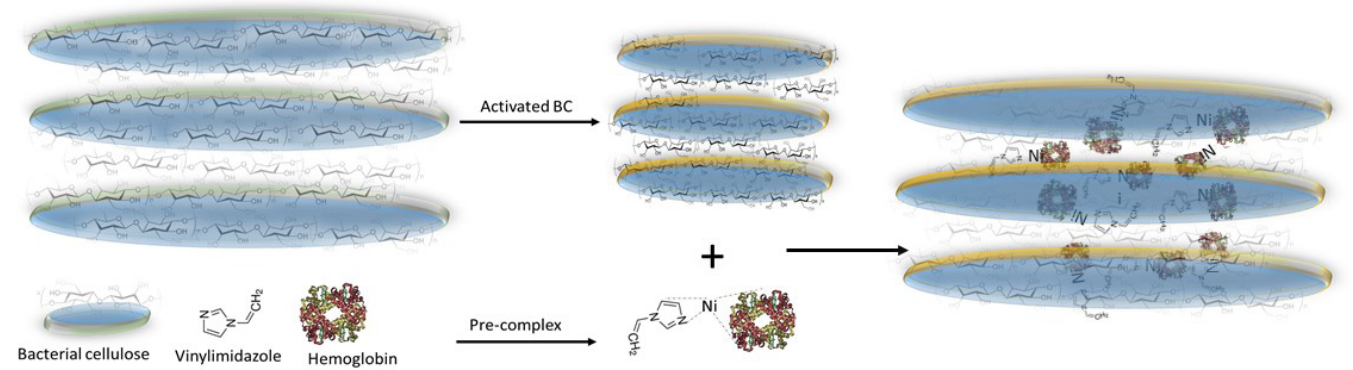

Figure 1. The schematic preparation of $\mathrm{Hb}$-imprinted $\mathrm{BC}$ nanofibers. 
Also, surface area, macroporosity, and swelling degree were studied. The specific surface areas of the bacterial celluloses were determined by the multipoint Brunauer-Emmett-Teller (BET) method (Quantachrome, Nova 2200E, USA). For macroporosity, and swelling degree, firstly the bacterial celluloses were dried (mdried) and weighed for the swelling properties of bacterial cellulose. Water was placed in a beaker and dry bacterial celluloses were immersed into the beaker. The wet nanofibers were removed from the beaker, wiped, and weighed (mwet). Macroporosity is calculated using the weight of the nanoparticles in its pores when the water is swollen and after being squeezed. Equation $(1,2)$ were used to determine the swelling degree and macroporosity.

$$
\begin{aligned}
& \text { Swelling degree }=\left(M_{w e t}-M_{d r y}\right) / M_{w e t} \\
& \text { Macroporosity } \%=\left(M_{w e t}-M_{s q}\right) / M_{\text {wet }}
\end{aligned}
$$

\section{Adsorption studies}

Plasma hemoglobin is a measure of circulating red blood cell destruction and is considered to be the basic indicator of intravascular hemolysis. In practice, clinicians generally consider anemia (circulating hemoglobin concentration $<120 \mathrm{~g} / \mathrm{l}$ in non-pregnant females and $<130$ $\mathrm{g} / \mathrm{l}$ in males) as due to impaired hemoglobin synthesis or increased erythrocyte loss or destruction.

The adsorption studies of $\mathrm{Hb}$ on the hemoglobin-imprinted and non-imprinted bacterial cellulose were done for $2 \mathrm{~h}$. The adsorption capacity was reported with 0.1 $2.0 \mathrm{mg} / \mathrm{mL} \mathrm{Hb}$ concentration. UV-Spectrophotometry at $280 \mathrm{~nm}$ was used for determining the amount of $\mathrm{Hb}$. The binding amount was calculated in Equation 3.

$Q=\left(C_{\text {initial }}-C_{\text {final }} / m\right) \times V$

Here, the binding amount of protein is showed with $\mathrm{Q}$ (mg $\mathrm{Hb} / \mathrm{g}$ ), and the initial, final $\mathrm{Hb}$ concentrations are showed with $\mathrm{C}_{\text {initial }}$ and $\mathrm{C}_{\text {final }}(\mathrm{mg} \mathrm{Hb} / \mathrm{mL})$. Also, the solution volume of hemoglobin is showed with $V(\mathrm{~mL})$. In the end, $m$ is used for the dried mass of bacterial cellulose membrane (g).

$\mathrm{Hb}$ imprinted onto the surface of bacterial cellulose nanofibers using metal ion coordination interactions bet- ween template protein molecules $(\mathrm{Hb})$ and functional monomer incorporated nickel ions. The combination of the imprinting strategy and metal ion coordination interactions exhibits selective recognition sites complementary to $\mathrm{Hb}$ molecules. Benefiting from the high surface area of bacterial cellulose nanofibers, $\mathrm{Hb}$ imprinted (MIP) bacterial cellulose nanofibers possess a high binding capacity for $\mathrm{Hb}$ purification.

\section{Reusability and selectivity studies}

One of the important advantages imprinting technology offers compared to other materials is their high chemical robustness, stability, providing the opportunity to clean and reactivate them under relatively harsh conditions for multiple uses in purification applications. Due to their high specificity, selectivity, good reproducibility, reusability, and efficient mass transfer molecularly imprinted-based materials have become attractive for researchers in the separation and purification of proteins. The reusability of the $\mathrm{Hb}$-imprinted bacterial cellulose were showed with utilizing $1.0 \mathrm{M} \mathrm{NaCl}$ in the rotator for $2 \mathrm{~h}$ at room temperature. This study was carried out by repeating 10 times of the adsorption and desorption experiments using the same bacterial cellulose membrane.

The selectivity studies for $\mathrm{Hb}$ were obtained with Myo, Cyt C, BSA, and Lyz. Four different competitive proteins Cyt c (MWcytc:12.3 kDa, pl: 10.6), Lyz (MWlyz: 14.6 kDa, pl: 10.5), Myo (MWmyo: 16.9 kDa, pl: 7.0), and BSA (MWbsa: 67.0 kDa, pl: 4.9) with different isoelectric point values and molecular weights were used to test the selectivity of hemoglobin imprinted nanofibers.

The study was done with a $1 \mathrm{mg} / \mathrm{mL}$ protein concentration at $\mathrm{pH}$ 7.4. The imprinting factor (IF) was reported by Equation 4;

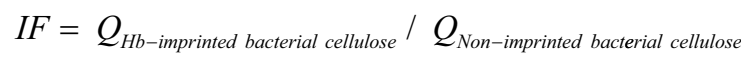
(4)

\section{RESULTS AND DISCUSSION}

\section{Characterization of bacterial cellulose}

The molar ratio of $\mathrm{VI}$ monomers and $\mathrm{Ni}^{2+}$ ions were selected 1:1 to obtain the extent complex between the functional monomer (imidazole group) onto the VI monomer and metal ions. Because of the $\mathrm{N}$ atoms in the hetero aromatic ring demonstrates Lewis base charac- 


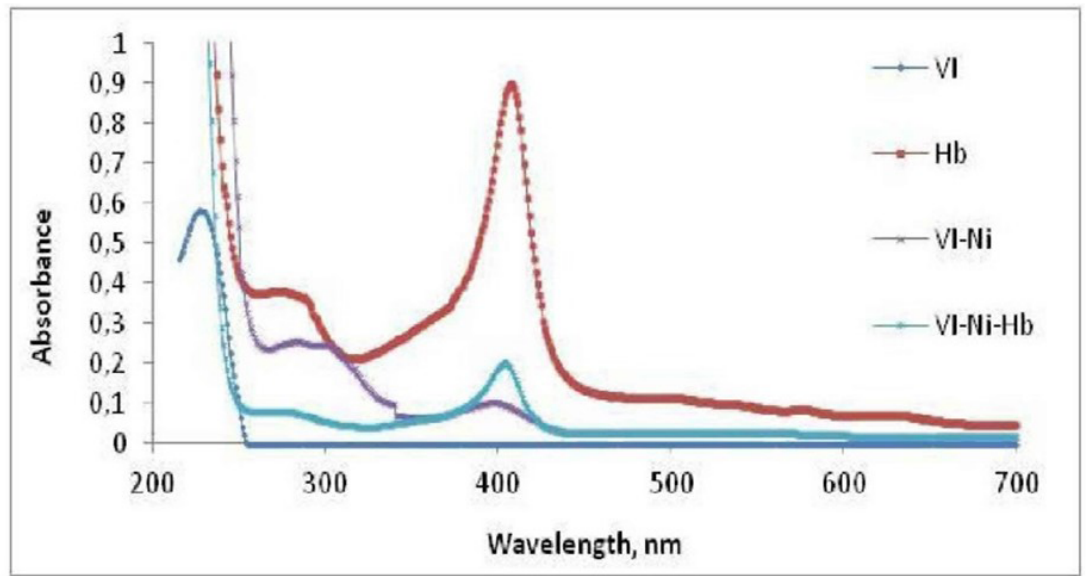

Figure 2. The UV spectrum of $\mathrm{Hb}, \mathrm{VI}-\mathrm{Ni} 2+$, and $\mathrm{VI}-\mathrm{Ni} 2+-\mathrm{Hb}$ pre-complex.

ter, therefore, the transition metal ions can be easily bond to the imidazole group.

Figure 2 shows UV-vis spectra of the interaction between $\mathrm{VI}$ monomer and $\mathrm{Ni}^{2+}$. The binding of the $\mathrm{VI}-\mathrm{Ni}^{2+}$ complex was confirmed by 2 same investigations. First investigation is the $350 \mathrm{~nm}$ shifting of the peak to the right side and the second is an appearance of a new peak in the $400 \mathrm{~nm}$. The colors of $\mathrm{VI-Ni}{ }^{2+}$ complexes turned greenish. When the polymerization onto the bacterial cellulose done, the colors of bacterial cellulose changed to the light green.
The FTIR spectra of bare, NIP and MIP bacterial cellulose showed that the characteristic peaks of VI as amide bands at $1600 \mathrm{~cm}^{-1}$ and $1735 \mathrm{~cm}^{-1}$, respectively. The broadband in the region of $3350-3330 \mathrm{~cm}^{-1}$ corresponds to $\mathrm{OH}$ stretching frequencies of cellulose structure, the band at around $1430 \mathrm{~cm}^{-1}$ is assigned to a symmetric $\mathrm{CH}_{2}$ bending vibration and the $\mathrm{C}-\mathrm{O}-\mathrm{C}$ glycosidic ether band arises at $\sim 109 \mathrm{~cm}^{-1}$. The presence of the amide bands in the FTIR spectra of MIP and NIP shows the binding of the Nickel metal ions chelating monomers onto the $\mathrm{BC}$ membranes structure (Figure 3 ).

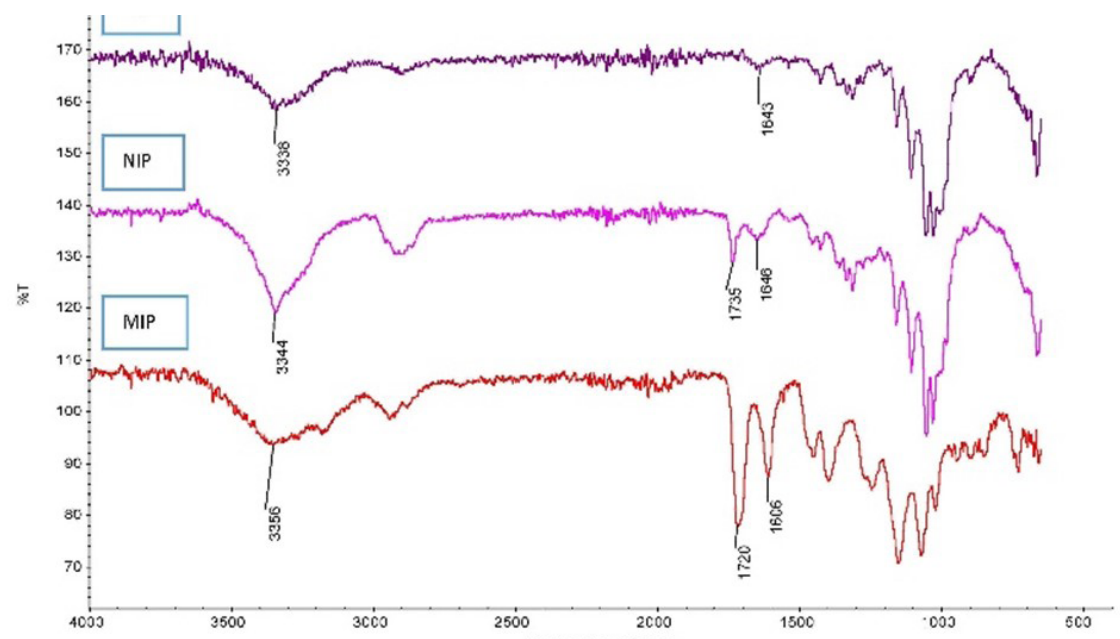

Figure 3. FTIR spectra of bare, MIP and NIP bacterial cellulose. 
Table 1. The several physical properties of the $B C$ nanofibers.

\begin{tabular}{cc}
\hline Items & Property \\
\hline Porosity & $84 \%$ \\
\hline Nanofiber diameter & $50-100 \mathrm{~nm}$ \\
\hline Contact angle & $28^{\circ}$ \\
\hline Thickness & $100 \mu \mathrm{m}$ \\
\hline Swelling & $2000 \%$ \\
\hline Surface area & $914 \mathrm{~m}^{2} / \mathrm{g}$
\end{tabular}

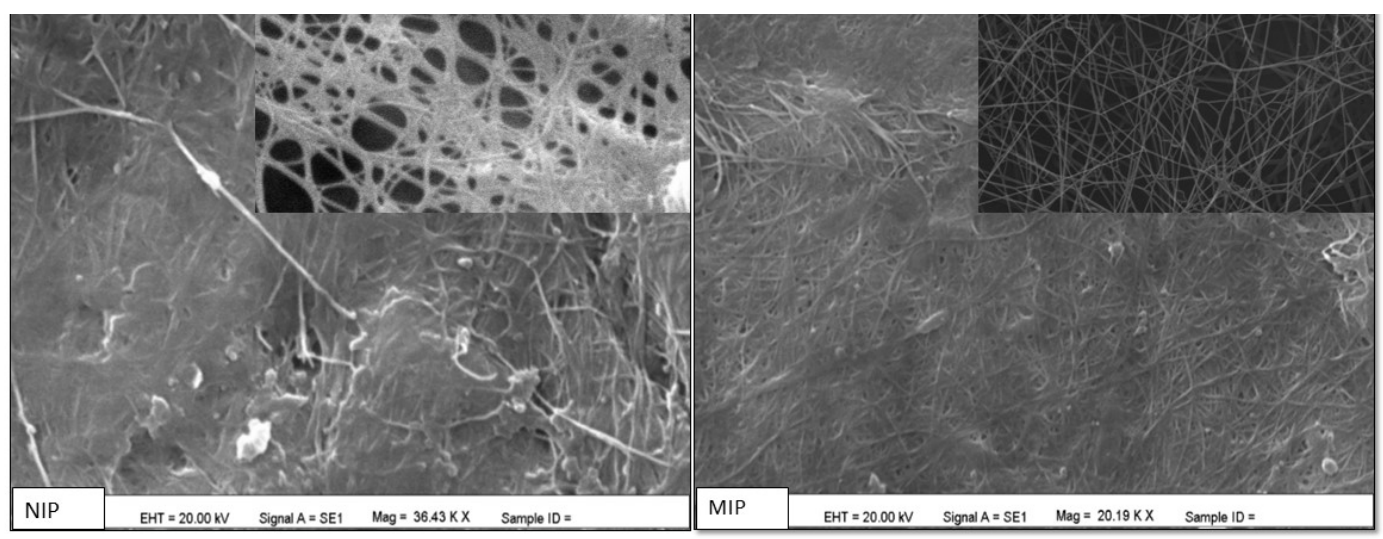

Figure 4. SEM micrograph of bacterial cellulose nanofibers.

Figure 4 shows the surface macroporosity and area of the bacterial cellulose that enable to transport of the target through the bacterial cellulose. The 3-dimensional structure of bacterial cellulose provides the easy diffusion of the target through the imprinting film prepared onto the matrices surface for purification and depletion applications. The equilibrium swelling percent of bacterial cellulose was obtained $2000 \%$. The porosity was also reported $84 \%$ and the surface area was $914 \mathrm{~m}^{2} / \mathrm{g}$ (Table 1). The nanofibers network of the bacterial cellulose nanofibers that enables fast binding of the proteins were shown in Figure 4 . The nanofiber diameter was 50-100 $\mathrm{nm}$.

\section{Adsorption studies}

Firstly, the $\mathrm{pH}$ effect was carried out for obtain the maximum adsorption capacity of $\mathrm{Hb}$. In this case the $\mathrm{pH}$ effect was studies in the range of $5.0-8.0,1.0 \mathrm{mg} / \mathrm{mL}$ $\mathrm{Hb}$ initial concentration. As seen in Figure $5 \mathrm{a}, \mathrm{pH} 7.4$ demonstrated maximum adsorption capacity. Therefore, this $\mathrm{pH}$ was selected in during the study. Figure $5 \mathrm{~b}$ are demonstrated the adsorption studies of the $\mathrm{Hb}$ onto the MIP bacterial cellulose. The binding of $\mathrm{Hb}$ was increased with the increase in the concentration of $\mathrm{Hb}$.
Also, the $\mathrm{Hb}$ binding capacity of imprinted bacterial cellulose was higher than the non-imprinted bacterial cellulose due to the selective recognition sites. The maximum adsorption capacity of hemoglobin onto the MIP and NIP bacterial cellulose nanofibers was found as $71.2 \mathrm{mg} / \mathrm{g}$ and $20.9 \mathrm{mg} / \mathrm{g}$, respectively. Also, the crosslinkers indicates the high stability in bacterial cellulose to recognition sites for $\mathrm{Hb}$ binding. It is clearly seen that MIP nanofibers have larger adsorption capacity than NIP nanofibers.

\section{Reusability and selectivity studies}

In order to show the stability and reusability studies of $\mathrm{Hb}$-imprinted bacterial cellulose membranes, the 10 cycles of the adsorption and desorption experiments were repeated using the same bacterial cellulose membranes $2 \mathrm{~h}$ at room temperature in the rotator with $20 \mathrm{rpm}$. It was realized that the membranes are highly stable. The adsorption capacity of the bacterial cellulose was reported at almost value of $95 \%$. After 10 times repeating, there was no significant decrease in the adsorption capacity of MIP bacterial cellulose nanofibers. 

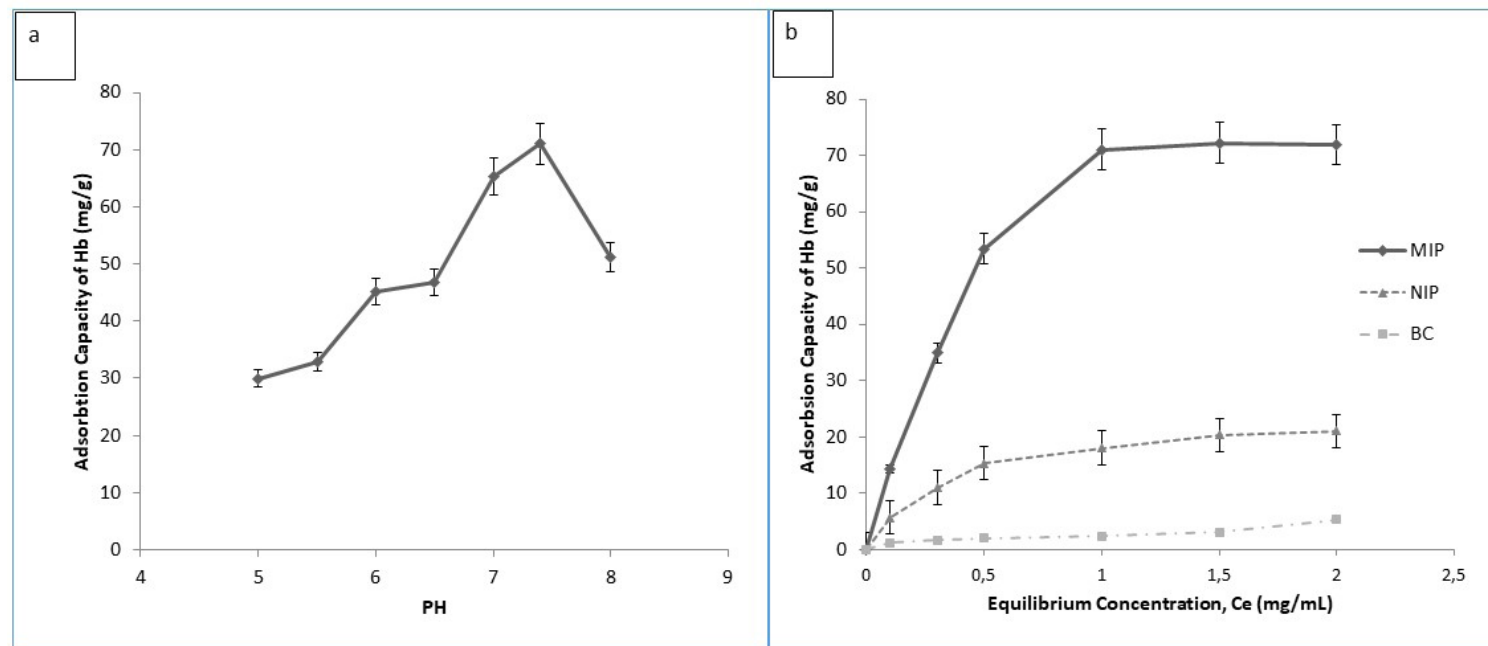

Figure 5. Effect of $\mathrm{pH}$, b. equilibrium MIP nanofibers on adsorption amount.

ights and also isoelectric point were utilized to show the sensitivity and selectivity of $\mathrm{Hb}$ based MIP bacterial cellulose membranes. The binding capacity of $\mathrm{Hb}$ imprinted and non-imprinted bacterial cellulose was showed using $1.0 \mathrm{mg} / \mathrm{mL}$ initial concentration of $\mathrm{Hb}$ at $\mathrm{pH}$ : 7.4. The shape memory of MIP bacterial cellulose and cross-linkers supplied the three-dimensional structure for $\mathrm{Hb}$ on the surface of MIP bacterial cellulose. Therefore, the imprinting factor was demonstrated high selectivity for $\mathrm{Hb}$ protein (Figure 6).

\section{Discussion}

Surface imprinting has been notified as one of the most commonly preferred approaches to be applied for imprinting of proteins. In the related literature, there have been some publications using biomaterials for the purification of $\mathrm{Hb}$. It was emphasized that molecular imprinted are suitable for the purification of proteins with selective and sensitive advantages. In a study, Baydemir et al. designed a composite cryogel that consisted of hemoglobin imprinted poly(2-hydroxyethyl methacrylate-N-methacryloyl-I-histidine) particles and 2-hydroxyethyl methacrylate cryogels with high gel fraction yield up to $90 \%$ for the depletion of hemoglobin [26]. In another study, Zhang and Li developed a facile approach to the construction of bio-recognition sites in silica nanoparticles for efficient separation of $\mathrm{Hb}$ through surface molecularly imprinting technology. The imprinted polymers possessed a maximum binding capacity up to $90.3 \mathrm{mg} / \mathrm{g}$ and high selectivity for the recognition of $\mathrm{Hb}$ [27]

When the history of $\mathrm{Hb}$ purification is searched, it can be clearly seen that molecular imprinting technology exploited as effectively as antibody recognition attempts. In another study, Zhang et al. prepared a robust, efficient, and cost-effective $\mathrm{Hb}$ purification strategy. They used molecularly imprinted polymers as a novel and efficient chromatographic resin to selectively recognize and purify different $\mathrm{Hb}$ variants. The dynamic binding capacity at $10 \%$ breakthrough was around $7.4 \mathrm{mg} / \mathrm{mL}$ resin for adult $\mathrm{Hb}$ and fetal $\mathrm{Hb}$ [28]. In other studies, Bagán et al. prepared protein-selective polymers as the epitope-imprinting approach, where surface-accessible peptides from a target protein are used as templates to create surface-exposed binding sites on molecularly imprinted polymers. They displayed new surface imprinted MIPs to high selectivity for $\mathrm{Hb}$, and separated different variants of $\mathrm{Hb}$ from protein mixtures [29].

Our previous researches $[12,15,30,31]$ in the field of imprinted bacterial cellulose for purification were all performed for proteins such as $\mathrm{Hb}$, lysozyme, cytochrome c. In the present study, it was aimed to purification $\mathrm{Hb}$ selected as a model using surface imprinted bacterial cellulose nanofibers. The purification mechanism could be attributed to the amino acids on the surface 
of the protein, which provide the interaction with $\mathrm{MAH}$ $\mathrm{Ni}(\mathrm{II})$ complex.

\section{Conclusion:}

A new technology based on surface imprinting was showed for the purification of $\mathrm{Hb}$. Hemoglobin imprinted bacterial cellulose nanofiber membranes were produced in this study with highly selectivity and sensitivity. Metal coordination with protein is well suited to use in surface imprinting technology due to its specificity and stability. Also, the cross-linking onto the bacterial cellulose generate a meaningful adsorption amount of hemoglobin molecules. The maximum $\mathrm{Hb}$ adsorption capacity of MIP bacterial cellulose nanofiber was found to be $71.2 \mathrm{mg} / \mathrm{g}$.

The reusability of MIP bacterial cellulose nanofiber was tested by performing 10 times adsorption-desorption cycles. After 10 times repeating, there was no significant decrease in the adsorption capacity of MIP bacterial cellulose nanofibers. The results offered here show that surface imprinting technology is able to fully purify a $\mathrm{Hb}$ in a single-purification step. This method is able to fabricate work for the purification of $\mathrm{Hb}$ from almost any other species. Molecularly imprinted-based materials are demonstrated high specificity, and good reproducibility, to use in the separation and purification of proteins.

\section{References}

1. Z. Liu,Y.Wang, F. Xu, X. Wei, J. Chen, H. Li, X. He, Y. Zhou, A new magnetic molecularly imprinted polymer based on deep eutectic solvents as functional monomer and cross-linker for specific recognition of bovine hemoglobin, Anal. Chim. Acta., 1129 (2020) 49-59.

2. S. Diken Gür, M. Bakhshpour, N. Bereli, A. Denizli, Antibacterial effect against both Gram-positive and Gram-negative bacteria via lysozyme imprinted cryogel membranes, J. Biomater. Sci. Polym. Ed., 0 (2021) 1-16.

3. N. Bereli, H. Yavuz, A. Denizli, Protein chromatography by molecular imprinted cryogels, J. Liq. Chromatogr. Relat. Technol., 43 (2020) 657-670.

4. J. Kalecki, Z. Iskierko, M. Cieplak, P.S. Sharma, Oriented Immobilization of Protein Templates: A New Trend in Surface Imprinting, ACS Sensors, 5 (2020) 3710-3720.

5. R. Xing, Y. Ma, Y. Wang, Y. Wen, Z. Liu, Specific recognition of proteins and peptides via controllable oriented surface imprinting of boronate affinityanchored epitopes, Chem. Sci. 10 (2019) 1831-1835.

6. S. Gorgieva, J. Trček, Bacterial cellulose: Production, modification and perspectives in biomedical applications, Nanomaterials, 9 (2019) 1-20.
7. G.F. Picheth, C.L. Pirich, M.R. Sierakowski, M.A. Woehl, C.N. Sakakibara, C.F. de Souza, A.A. Martin, R. da Silva, R.A. de Freitas, Bacterial cellulose in biomedical applications: A review, Int. J. Biol. Macromol., 104 (2017) 97-106.

8. F.G. Torres, J.J. Arroyo, O.P. Troncoso, Bacterial cellulose nanocomposites: An all-nano type of material, Mater. Sci. Eng. C, 98 (2019) 1277-1293.

9. M. Moniri, A.B. Moghaddam, S. Azizi, R.A. Rahim, A. Bin Ariff, W.Z. Saad, M. Navaderi, R. Mohamad, Production and status of bacterial cellulose in biomedical engineering, Nanomaterials, 7 (2017) 1-26.

10. B. V. Mohite, S. V. Patil, A novel biomaterial: Bacterial cellulose and its new era applications, Biotechnol. Appl. Biochem., 61 (2014) 101-110.

11. C., Buruaga-Ramiro, S.V., Valenzuela, C. Valls, et al. Bacterial cellulose matrices to develop enzymatically active paper, Cellulose, 27 (2020) 3413-3426.

12. Y. Saylan, E. Tamahkar, A. Denizli, Recognition of lysozyme using surface imprinted bacterial cellulose nanofibers, J. Biomater. Sci. Polym. Ed., 28 (2017) 1950-1965.

13. E. Tamahkar, M. Bakhshpour, A. Denizli, Molecularly imprinted composite bacterial cellulose nanofibers for antibiotic release, J. Biomater. Sci. Polym. Ed., 30 (2019) 450-461.

14. Y. Saylan, IIgım Göktürk, K. Pospiskova, I. Safarik, A. Denizli, Magnetic bacterial cellulose nanofibers for nucleoside recognition, Cellulose, 27 (2020) 94799492.

15. M. Bakhshpour, E. Tamahkar, M. Andaç, A. Denizli, Surface imprinted bacterial cellulose nanofibers for hemoglobin purification, Colloids Surf. B Biointerfaces, 158 (2017) 453-459.

16. M. Liu, S. Li, Y. Xie, S. Jia, Y. Hou, Y. Zou, C. Zhong, Enhanced bacterial cellulose production by Gluconacetobacter xylinus via expression of Vitreoscilla hemoglobin and oxygen tension regulation, Appl. Microbiol. Biotechnol., 102 (2018) 1155-1165.

17. H. Bagán, T. Zhou, N.L. Eriksson, L. Bülow, L. Ye, Synthesis and characterization of epitope-imprinted polymers for purification of human hemoglobin, RSC Adv., 7 (2017) 41705-41712.

18. K. Zhang, T. Zhou, K. Kettisen, L. Ye, L. Bülow, Chromatographic separation of hemoglobin variants using robust molecularly imprinted polymers, Talanta, 199 (2019) 27-31.

19. J. Elmer, D. Harris, A.F. Palmer, Purification of hemoglobin from red blood cells using tangential flow filtration and immobilized metal ion affinity chromatography, J. Chromatogr. B Anal. Technol. Biomed. Life Sci., 879 (2011) 131-138.

20. H. Yavuz, V. Karakoç, D. Türkmen, R. Say, A. Denizli, Synthesis of cholesterol imprinted polymeric particles, Int. J. Biol. Macromol., 41 (2007) 8-15.

21. N.F., Vasconcelos, F.K., Andrade, L.d.A.P. Vieira, et al. Oxidized bacterial cellulose membrane as support for enzyme immobilization: properties and morphological features, Cellulose, 27 (2020) 3055-3083.

22. B. Demirci, N. Bereli, S. Aslıyüce, G. Baydemir, A. Denizli, Protein $C$ recognition by ion-coordinated imprinted monolithic cryogels, J. Sep. Sci., 40 (2017) 1610-1620. 
23. S. Mallik, R.D. Johnson, F.H. Arnold, Selective Recognition of Bis-Imidazoles by Complementary BisMetal Ion Complexes, J. Am. Chem. Soc., 115 (1993) 2518-2520.

24. M. Bakhshpour, E. Tamahkar, M. Andaç, A. Denizli, Affinity binding of proteins to the modified bacterial cellulose nanofibers, J. Chromatogr. B, 10522017 (2017) 121-127.

25. S. Akgönüllü, M. Bakhshpour, N. İdil, M. Andaç, H. Yavuz, A. Denizli, Versatile polymeric cryogels and their biomedical applications, Hacettepe J. Biol. Chem., 48 (2020) 99-118.

26. G. Baydemir, M. Andaç, I. Perçin, A. Derazshamshir A. Denizli, Molecularly imprinted composite cryogels for hemoglobin depletion from human blood. J. Mol. Recognit., 27 (2014) 528-536.

27. Z. Zhang, L. Li, Efficient synthesis of molecularly imprinted polymers with bio-recognition sites for the selective separation of bovine hemoglobin, J. Sep. Sci., 41 (2018) 2479-2487.
28. K. Zhang, T. Zhou, K. Kettisen, L. Ye, L. Bülow, Chromatographic separation of hemoglobin variants using robust molecularly imprinted polymers, Talanta, 199 (2019) 27-31.

29. H. Bagán, T. Zhou, N.L, Eriksson, L. Bülow, L. Ye, Synthesis and characterization of epitope-imprinted polymers for purification of human hemoglobin, RSC Adv., 7 (2017) 41705-41712.

30. E. Tamahkar, N. Bereli, R. Say, A. Denizli, Molecularly imprinted supermacroporous cryogels for cy tochrome c recognition, J. Sep. Sci., 34 (2011) 3433-3440.

31. Emel Tamahkar, Tülin Kutsal, Adil Denizli, Surface imprinted bacterial cellulose nanofibers for cytochrome c purification, Process Bioch., 50 (2015) 2289-2297. 